\title{
Kompost Mikrobiyal Yakıt Hücreleri İçin Titanyum Elektrot Performansının İncelenmesi
}

\author{
Nurettin Çek $^{1 *}$, Ahmet Erensoy ${ }^{2}$ \\ ${ }^{1}$ Firat Üniversitesi, Mühendislik Fakültesi, Metalurji ve Malzeme Mühendisliği Bölümü, Elazı̆̆, Türkiye, (ORCID: 0000-0001-6120-9228) \\ ${ }^{2}$ Fırat Üniversitesi, Tıp Fakültesi, Parazitoloji Bölümü, Elazığ, Türkiye, (ORCID: 0000-0001-6300-1105)
}

(İlk Geliş Tarihi 12 Kasım 2019 ve Kabul Tarihi 6 Aralık 2019)

(DOI: 10.31590/ejosat.650717)

ATIF/REFERENCE: Çek, N., \& Erensoy, A. (2019). Kompost Mikrobiyal Yakıt Hücreleri İçin Titanyum Elektrot Performansının İncelenmesi. Avrupa Bilim ve Teknoloji Dergisi, (17), 909-915.

$\ddot{O} \mathbf{z}$

Mikrobiyal yakıt hücresi, hem atıksu arıtımı hem de elektrik üretiminin aynı anda gerçekleştiği güzel bir enerji üretim teknolojisidir. Yeşil enerjiye olan talep artıyor ve mikrobiyal yakıt hücreleri gibi biyoelektrokimyasal cihazlar bu amaç için kullanılabilir. Kompost mikrobiyal yakıt hücresi, kompost malzemelerden elektrik enerjisi üretmenin umut verici bir yoludur. Bir kompost mikrobiyal yakıt hücresinde, organik kompost malzemeleri, mikrobiyal yakıt hücresindeki bakterilerle ayrışır ve organik materyallerdeki mikrobiyal etki ile biyoenerji üretmek için kullanılır. Kompost malzemelerinden salınan organik madde, organik maddelerin yakınında toprakta bulunan bakteriler tarafindan elektronlara ve protonlara dönüştürülür. Elektronlar, anot elektrottan ve dış devreden katot elektrotuna gider. Protonlar, elektrolit aracılığıly katot elektrotuna gider. Elektronlar, protonlar ve havadan gelen oksijen katod elektrodunda birleşir. Böylece, mikrobiyal yakıt hücresi elektrik enerjisi ve su üretir. Bu çalışmada, farklı miktarlarda organik kompost malzemelerle beslenen, elektrotlar olarak titanyum plakaları olan, tek odacıklı, membransız mikrobiyal yakıt hücreleri 10 gün boyunca çalıştırıldı. Ağırlıkça \% 1, \% 10 ve\% 20 kompost malzemeleri içeren mikrobiyal yakıt hücreleri, sirasıyla, MYH-I, MYH-II ve MYH-III olarak adlandırılmıştır. Elde edilen maksimum enerji, $4.025 \mathrm{~mW} / \mathrm{m}^{2}$ değerinde bir maksimum güç yoğunluğu ile ifade edildi ve bu değer MYH-III'e aittir. Kompost mikrobiyal yakıt hücrelerinin açık devre gerilimleri (Voc) 10 günlük çalışma sırasında zamanla değişir. MYH I, MYH-II ve MYH-III'ün en yüksek açık devre gerilimleri sırasıyla $375 \mathrm{mV}, 380 \mathrm{mV}$ ve $383 \mathrm{mV}$ olarak ölçülmüş̧ür. Bu çalışmada mikroskop görüntüleri ile görüntülenen coccus türü bakteriler, MYH-I, MYH-II ve MYH-III için biyokatalizör görevi gördü. Bu çalı̧̧ma, titanyum elektrotların kompost mikrobik yakıt hücreleri için elektrik üretme kabiliyetine sahip olduğunu göstermiştir. İlaveten, titanyum elektrotlarının karbon bezi, grafit, grafen oksit gibi elektrotlara alternatif bir elektrot olduğu bulunmuştur.

(Minimum 250 - Maksimum 400 kelime ve içeriğinde amaç, materyal-metot, bulgular ve sonuç kısımlarını içerecek şekilde yazilmalıdır.)

Anahtar Kelimeler: Mikrobiyal yakıt hücresi, Titanyum, Organik malzeme, Kompost.

\footnotetext{
${ }^{*}$ Sorumlu Yazar: Firat Üniversitesi, Mühendislik Fakültesi, Metalurji ve Malzeme Mühendisliği Bölümü, Elazığ, Türkiye, ORCID: 0000-0001-61209228, nurettincek001@gmail.com
} 


\title{
Examination of Titanium Electrode Performance for Compost Microbial Fuel Cells
}

\begin{abstract}
Microbial fuel cell is a nice energy production technology where both wastewater treatment and electricity generation take place concurrently. There is increasing demand for green energy, and bioelectrochemical devices, such as microbial fuel cells, can be used for this goal. The compost microbial fuel cell is one promising way to produce electrical energy from compost materials. In a compost microbial fuel cell, organic compost materials are decomposed with the bacteria at the microbial fuel cell and used to generate bioenergy by the microbial action on organic materials. The organic matter released through from compost materials is converted into electrons and protons by the bacteria present in soil near the organic materials. The electrons are go to to cathode electrode through from anode electrode and the external circuit. Protons are go to the cathode electrode through the electrolyte. The electrons, protons, and oxygen from air combine in the cathode electrode. Thus, the microbial fuel cell produces electrical energy and water. In this study, the single chambered, non-membrane microbial fuel cells with titanium plates as electrodes, fed with the different quantities organic materials of compost, were run for 10 days. Microbial fuel cells containing $1 \%, 10 \%$ and $20 \%$ by weight of compost materials were named as MYH-I, MYH-II and MYH-III, respectively. The maximum energy obtained was expressed by a maximum power density of $4.025 \mathrm{~mW} / \mathrm{m}^{2}$ value and this value belongs to MYH-III. The open circuit voltages (Voc) of compost microbial fuel cells varies over time in 10 days of operation. The highest open circuit voltages of MYH I, MYH-II and MYH-III were measured as 375 $\mathrm{mV}, 380 \mathrm{mV}$ and $383 \mathrm{mV}$, respectively. In this study, coccus type bacteria, which were imaged with microscope images, acted as biocatalysts for MYH I, MYH-II and MYH-III. This study demonstrated that titanium electrodes has the ability to produce electricity for compost microbial fuel cells. In addition, titanium electrodes have been found to be an alternative electrode to electrodes such as carbon cloth, graphite, graphene oxide.
\end{abstract}

(Minimum 250 - Maximum of 400 words and content should be written in a way to include material, method, findings and results.)

Keywords: Microbial fuel cell, Titanium, Organic materials, Compost.

\section{Giriş}

Küresel ısınma ve çevrenin bozulması, küresel nüfus ve ekonomideki sürekli büyüme nedeniyle artan fosil yakıt kullanımı ile birlikte artmaktadır (Baykara (2018)). Avrupa Birliği, 2020 yllına kadar toplam enerji tüketiminin \% 20'sini yenilenebilir enerji kaynaklarını kullanarak karşılamayı hedeflemektedir. 2013 yılında yenilenebilir enerji kaynaklarından üretilen elektriğin, elektrik tüketimine katkısı \% 25.4 olup burada biyokütle ve atıklar en önemli enerji kaynakları olmuştur (Garita-Meza ve ark. (2018)). Biyokütle enerjisi temiz ve yenilenebilir bir enerji kaynağıdır (Çek (2013)).

Organik atık malzemenin biyoelektrik üretimi yapılarak geri kazanımı, hem gelişmiş ülkelerde hem de gelişmekte olan ülkelerde önemli bir konu haline gelmiştir. Örneğin; Japonya'daki gıda endüstrisi ve mutfak çöplerinden yıllık yaklaşık 20 milyon ton organik atık üretilmektedir (Moqsud ve ark (2013)). Mikrobiyal yakıt hücreleri kullanılarak organik atıklardan veya atık sulardan elektrik üretmek için bazı araştırmalar yapılmıştır. Denizlerdeki organik madde çökeltileri, pirinç çeltik tarlaları, kompostlanmış mutfak atıkları, kompastlanmış toprak, kavak ağacı gibi bitkisel malzemeler mikrobiyal yakıt hücrelerinde elektrik enerjisi üretmek için kullanılmışlardır (Çek (2016a); Çek (2017); Erensoy ve Çek (2018); Moqsud ve ark. (2015)). Organik maddenin enerji içeriği, organik maddenin bakteriler tarafından parçalanma performansı, elektrotların bakterilerle uyumluluğu, elektrotların elektriksel ve korozyon dirençleri gibi faktörler mikrobiyal yakıt hücrelerinin elektrik üretim performansını etkileyen temel unsurlardandır (Pareek ve ark. (2019)).

Mikrobiyal yakıt hücreleri, yeşil ve yenilenebilir elektrik enerjisi üretimi için kullanılan cihazlardan birisidir. Mikrobiyal yakıt hücreleri biyoenerji tabanlı gelişmekte olan bir teknoloji olup onların sayesinde organik maddelerin sahip olduğu biyoelektrokimyasal enerji bakterilerin kataliz tepkimeleri vasıtasıyla doğrudan elektrik enerjisine çevrilmektedir (Çek (2016a); Çek (2017); Erensoy ve Çek (2018); Moqsud ve ark. (2013); Maqsud ve ark. (2015)). Bir biyoelektrik uygulaması olan mikrobiyal yakıt hücreleri elektrik üretirken aynı zamanda atık su arıtımı yapabilmekte olduğu için çevre üzerindeki karbon ayakizini düşürme potansiyeline sahiptir (Pareek ve ark. (2019)). Mikrobiyal yakıt hücrelerinin uzun süreli ve yerinde çalışma özelliklerinden dolayı sıcaklık, krom (VI) konsantrasyonu, mikrobiyal metabolizma gibi çevresel ve ekolojik koşulların gerçek zamanlı olarak algılanmasını sağlayan kablosuz sensörler olarak kullanıldığı bildirilmiştir (Wang ve Jiang (2019)).

Kompost bazlı mikrobiyal yakıt hücreleri temel olarak atık sudaki kirlenmenin giderilmesine ve daha yakın zamanda organik katı atıkların kompost haline getirme işlemlerinin geliştirilmesine odaklanmıştır (Garita-Meza ve ark. (2018)). Karbon bez elektrotların kullanıldığı kompost mikrobiyal yakıt hücresi ile ilgili yapılan bir araştırmaya göre komposttan tek başına elde edilen en yüksek elektriksel güç yoğunluğunun $4 \mathrm{~mW} / \mathrm{m}^{2}$ değerinde olduğu ve bu değerin kullanılabilirlik yönüyle çok düşük olduğu ifade edilmiştir (Nandy ve ark. (2015)). Bununla birlikte, kolay temin edilebilen, bahçe kompostu gibi patojenik olmayan malzemeler mikrobiyal yakıt hücrelerinde kullanıldığında bir ev ortamı için enerji ihtiyacının bir kısmını karşılamak için kullanılabilir. Dahası, bu yaklaşım yeşil elektrik kullanımına izin vereceği ve gerçek ekolojik eğilimlerle tutarlı olduğu ifade edilmiştir (Garita-Meza ve ark. (2018)). 
Bu çalışmada, toprak içerisine farklı oranlarda bitki ve hayvan artıklarından elde edilen kompost yerleştirilmiş ve organik bir karışım oluşturulmuştur. Sonra, bu karışımdaki organik malzemelerden faydalanarak elektrik üreten kompost mikrobiyal yakıt hücresi imal edilmiştir. Bu mikrobiyal yakıt hücrelerinde, titanyum esaslı elektrot malzemelerinin elektriksel, kimyasal, mikrobiyal özelliklere ve güç üretim performansına etkisi ortaya çıkarılmıştır. Daha sonra, bu çalışma önceki çalışmalarla kıyaslanmış ve farklar ortaya konulmuştur.

\section{Materyal ve Metot}

\subsection{Materyal}

Titanyum levha elektrot; \%99.9 saflıkta, 53.38 gram ağırlığında, $8 \mathrm{~cm}$ uzunluğunda, $3 \mathrm{~cm}$ genişliğinde ve $0.5 \mathrm{~cm}$ kalınlığındadır ( $8 \mathrm{cmx} 3 \mathrm{cmx} 0.5 \mathrm{~cm}=12 \mathrm{~cm}^{2}$ ). Dijital multimetre (UNI-T:UT61C); doğru akım volt ve akım değerlerini ölçer. Direnç; 10-220000 ohm

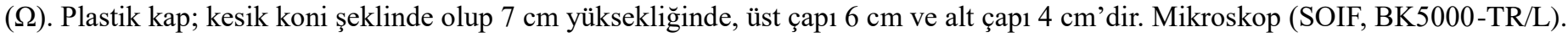

\subsection{Metot}

3 adet plasitik kabın her birinin içerisine 50 gram doğal toprak yerleştirilmiş ve sırasıyla toprak ağırlığının \% 1'i, \% 10’u ve \%20'si kadar bitki ve hayvan atıklarından oluşmuş organik kompost malzeme yerleştirilmiştir. Toprak içeren plastik kapların içersinde $\%$ 1, \% 10 ve \%20 oranında kompost malzeme içeren hücreler, sırasıyla MYH-I, MYH-II ve MYH-III olarak adlandırılmıştır. Daha sonra, her bir plastik kap içerisine birer adet titanyum anot elektrot ve birer adet titanyum katot elektrot yerleştirilmiştir. Tüm hücreler içerisine 50 mililitre su eklenerek elektrokimyasal tepkimelerin başlanması sağlanmıştır. Böylece üç tür mikrobiyal yakıt hücresi ortaya çıkarılmıştır. Daha önceki çalışmalarda olduğu gibi, bu mikrobiyal yakıt hücreleri iç dirençlerinin daha az olması ve güç yoğunluklarının daha yüksek olması için membransız ve tek odacıklı olarak imal edilmiştir (Çek (2017); Erensoy ve Çek (2018); Florio ve ark. (2019)). Ayrıca bu çalışmadaki mikrobiyal yakıt hücrelerinin titanyum katot elektrotları ihtiyaç duydukları oksijeni havadan sağlamaktadırlar.

Mikrobiyal yakıt hücrelerinin açık devre gerilimi (Voc) ve kısa devre akımı (Isc) değerleri multimetre cihazıyla zamana göre izlenmiştir. Mikrobiyal yakıt hücresi sabit açık devre voltajı ve sabit kısa devre akımı ürettiğinde 10-220000 $\Omega$ dış direnç ve multimetre kullanılarak kutuplaşma (polarizasyon) eğrisi elde edilmiştir. Mikrobiyal yakıt hücrelerinin güç yoğunluğu eğrisi denklem (1) kullanılarak oluşturulmuştur.

$$
\text { Güç yoğunluğu}=\frac{V x I}{S}
$$

Burada, V kutuplaşma eğrisindeki gerilim değerini (V), I kutuplaşma eğrisindeki akım değerini (A) ve S anot elektrotun geometrik yüzey alanını $\left(\mathrm{m}^{2}\right)$ ifade etmektedir.

Daha sonra mikrobiyal yakıt hücresinin elektrik üretim performansı tespit edilerek daha önceki çalışmalarla karşıllaştırılmıştır. Ayrıca kompost mikrobiyal yakıt hücresi için hem kimyasal analizler hem de mikrobiyal analizler yapılmıştır.

Bahsedilen mikrobiyal yakıt hücresinin şematik diyagramı Şekil 1'de gösterilmiştir.

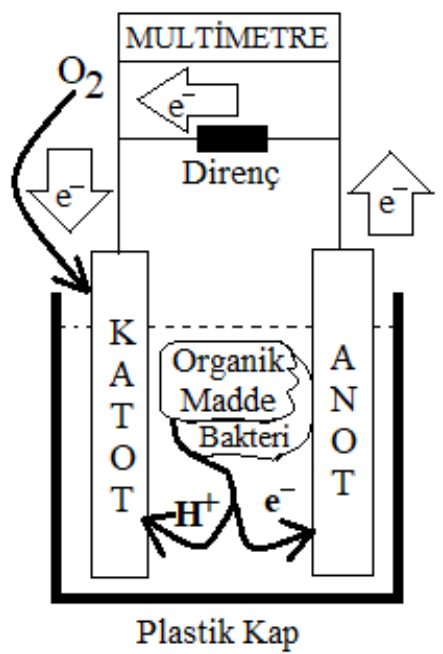

Şekil 1. Mikrobiyal yakıt hücresi deney düzeneği

\section{Araştırma Sonuçları ve Tartışma}

\subsection{Kimyasal ve mikrobiyolojik analiz}

$\mathrm{Bu}$ çalışmadaki mikrobiyal yakıt hücrelerinde hem anot elektrot hem katot elektrot olarak titanyum levha elektrotlar kullanılmıştır. Titanyum elektotlar yüksek korozyon direncine sahip biyouyumlu malzemelerdir (Güven (2014)). Bu çalışmadaki 
mikrobiyal yakıt hücrelerinin titantum katot elektrotları ihtiyaç duydukları oksijeni havadan temik ettikleri için hava katot olarak ifade edilir (Florio ve ark. (2019)).

Kompost; çeşitli bitki ve hayvan artıklarının doğada bakteriler tarafından ayrıştırılması sonucu ortaya çıkan organik bir maddedir. Kompostlanmış toprak ise organik madde bakımından zengin olan topraktır. Bu çalışmadaki kompost mikrobiyal yakıt hücresinde sulu bir kompostlanmış toprak kullanılmıştır. Sulu kompostlanmış toprak hem organik madde kaynağıdır hem bakterilerin yaşam alanıdır hem de iyon taşınımının yapıldığı elektrolittir. Kompostlanmış toprak içerisinde bulunan bakteriler komposttaki organik maddeleri ayrıştırmakta ve elektron ve protonları (hidrojen iyonları $\left(\mathrm{H}^{+}\right)$) açığa çıkarmaktadır (Çek (2016a); Çek (2017); Erensoy ve Çek (2018); Moqsud ve ark. (2013); Maqsud ve ark. (2015)). Elektron, elektriksel ve kimyasal etkileşimi gerçekleştirmektedir ve negatif yüklüdür. Proton, pozitif yüklüdür (Çek (2016b)). Açığa çıkan elektronlar, elektroliti kullanarak anot elektrota gitmektedirler. Oradan da dış devre yoluyla katot elektrota gitmektedirler. Protonlar ise elektrolit vasitasıyla katot elektrota gitmektedirler. Anottan gelen elektronlar, havadan alınan oksijen ve elektrolit vasıtasıyla gelen protonlar katotta birleşerek yük dengesini sağlamaktadırlar. Böylece, kompost mikrobiyal yakıt hücresi elektrik enerjisi ve su üretmektedir (Çek (2016a); Çek (2017); Erensoy ve Çek (2018); Moqsud ve ark. (2013); Maqsud ve ark. (2015); Pareek ve ark. (2019)).

$\mathrm{Bu}$ çalışmadaki, kompostlanmış toprak içerisinde coccus türü bakterileri deneylerden önce ve deneylerden sonra mikroskop görüntülenmiştir. Mikroskop görüntüleri Şekil 2'de gösterilmiştir.

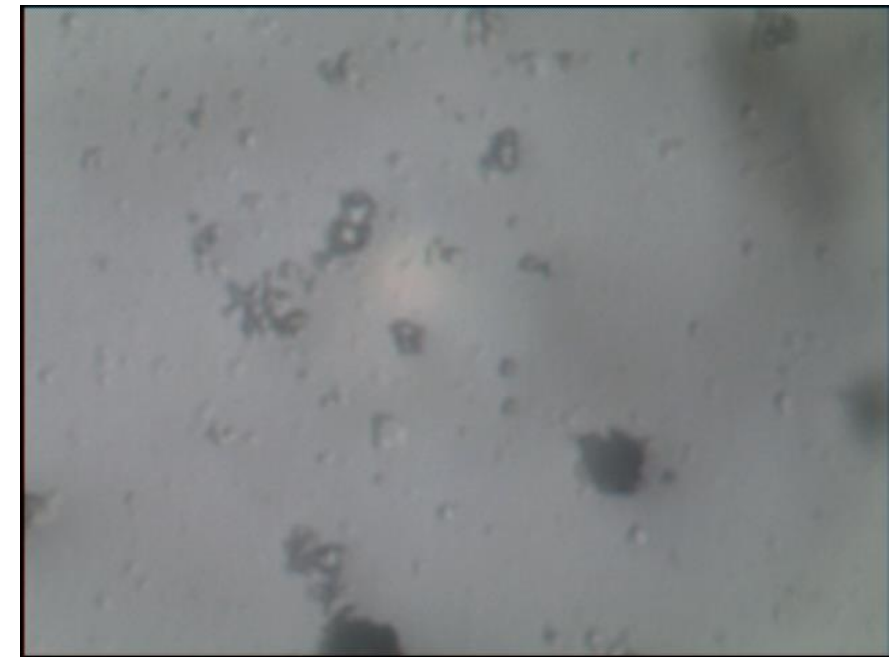

a) Deneylerden önceki görüntüler

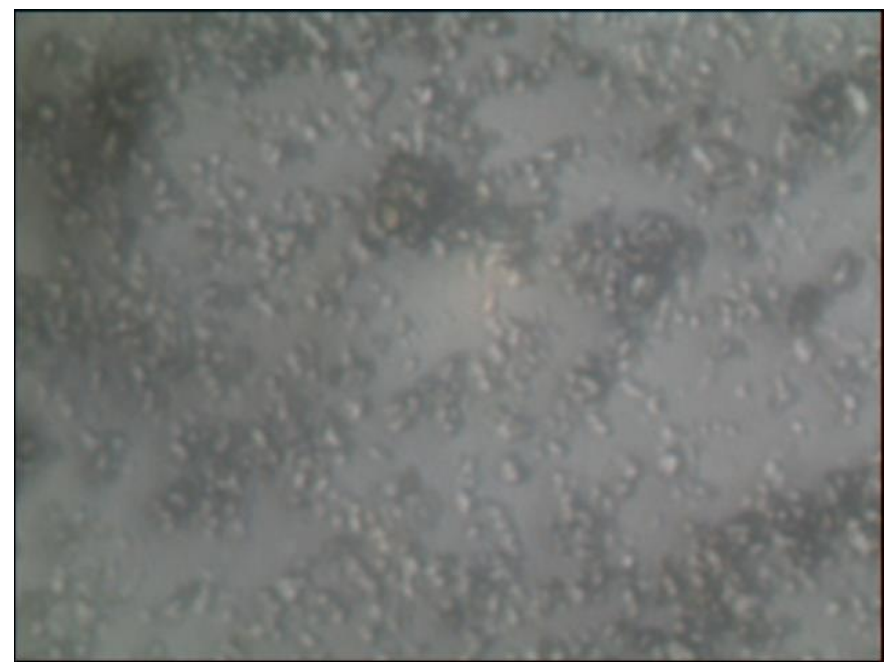

b) Deneylerden sonraki görüntüler

Şekil 2. Kompost topraktaki coccus bakterilerinin mikroskop görüntüsü

Şekil 2'deki coccus türü bakteriler çürükçül bakteriler olup kompost toprak içerisinde mevcut olan organik maddeyi ayrıştırma işlemini gerçekleştirmektedirler. Coccus türü bakteriler, organik maddeyi ayrıştırarak organik maddeden elektron ve protonları açığa çıkarmaktadır (Erensoy ve Çek (2018)). Bu nedenle, coccus türü bakteriler, bu çalışmadaki mikrobiyal yakıt hücresi için biyokatalizör görevini üstlenmişlerdir.

\subsection{Elektrokimyasal analiz}

Mikrobiyal yakıt hücrelerinin performansını incelemek için, açık devre potansiyeli (Voc) ve kısa devre akımı (Isc) değerleri gereklidir. Çünkü bu değerler sabit olduğunda, mikrobiyal yakıt hücrelerine değişken diş dirençler bağlanarak kutuplaşma eğrileri ve güç yoğunluğu eğrileri elde edilir (Maqsud ve ark. (2013); Moqsud ve ark. (2015); Erensoy ve Çek (2018); Pareek ve ark. (2019); Wang ve Jiang (2019)). Kompost microbiyal yakıt hücrelerinin açık devre (Voc) koşullarında ve kısa devre (Isc) koşullarında ürettikleri elektriksel enerji zamana bağlı olarak multimetre cihazı ile ölçüldü ve elde edilen sonuçlar Tablo 1'de mevcuttur.

Tablo 1. Mikrobiyal yakıt hücrelerinin zamana bă̆lı Voc ve Isc değerleri

\begin{tabular}{|c|c|c|c|c|c|c|}
\hline \multirow{2}{*}{$\begin{array}{l}\text { Zaman } \\
(\text { Gün})\end{array}$} & \multicolumn{2}{|c|}{ MYH-I } & \multicolumn{2}{c|}{ MYH-II } & \multicolumn{2}{c|}{ MYH-III } \\
\cline { 2 - 7 } & Voc $(\mathrm{mV})$ & Isc $(\mu \mathrm{A})$ & Voc $(\mathrm{mV})$ & Isc $(\mu \mathrm{A})$ & Voc $(\mathrm{mV})$ & Isc $(\mu \mathrm{A})$ \\
\hline 1. & 181 & 2 & 138 & 1.8 & 176 & 2.5 \\
\hline 2. & 230 & 2.3 & 239 & 2.5 & 248 & 3 \\
\hline 3. & 334 & 1.4 & 337 & 2.9 & 315 & 3.2 \\
\hline 4. & 373 & 1.9 & 375 & 2.3 & 377 & 3.8 \\
\hline 5. & 375 & 2 & 375 & 2.4 & 367 & 4.1 \\
\hline 6. & 364 & 1.7 & 379 & 2.8 & 353 & 4.4 \\
\hline 7. & 332 & 1.5 & 361 & 2.7 & 337 & 4.3 \\
\hline 8. & 297 & 1.4 & 353 & 2.3 & 366 & 5.1 \\
\hline 9. & 270 & 1.2 & 349 & 2.2 & 383 & 6 \\
\hline 10. & 270 & 1.2 & 349 & 2.2 & 383 & 6 \\
\hline
\end{tabular}


Tablo 1'deki sonuçlara göre kompost mikrobiyal yakıt hücrelerinde, en yüksek açık devre gerilimi ve en yüksek kısa devre akımı değeri MYH-III'tedir ve bu değerler $383 \mathrm{mV}$ ve $6 \mu \mathrm{A}$ olarak ölçülmüştür. Ayrıca, tüm mikrobiyal yakıt hücrelerinde zamana bağlı olarak ilk günden itibaren yükselen Voc ve Isc değerleri MYH-I'de 5. günden itibaren, MYH-II'de 6. günden itibaren azalırken MYHIII’te 10 gün boyunca azalmamış, 9.günden itibaren sabit kalmıştır. Yani, MYH-III daha istikrarlı bir performans sergilemiştir.

Mikrobiyal yakıt hücrelerini incelerken, kutuplaşma çalışmaları güç kayıplarını tanımlamak için çok yararlıdır. Kompost mikrobiyal yakıt hücreleri, sabit çıkış gerilimi ile sabit akım değeri ürettiklerinde dış direnç değeri 10 ile 220000 ohm $(\Omega)$ arasında değiştirilerek multimetre cıhazıyla elde edilen kutuplaşma (polarizasyon) eğrisi Şekil 3 ’te mevcuttur. Bu şekil, kompost mikrobiyal yakıt hücrelerindeki gerilim ve akım arasındaki ilişkiyi gösterir.

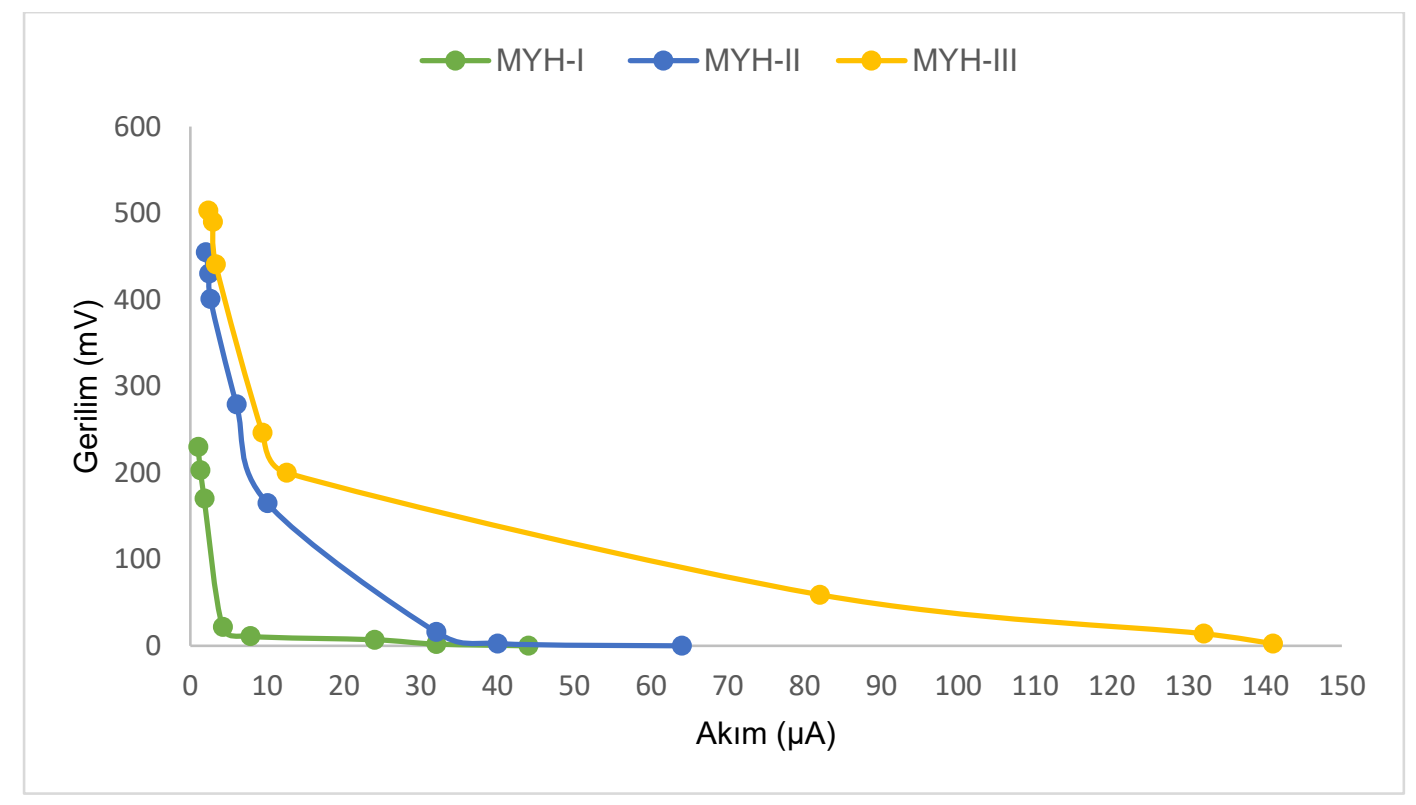

Şekil 3. Mikrobiyal yakıt hücrelerinin kutuplaşma eğrileri

Şekil 3'e göre, kompost mikrobiyal yakıt hücrelerinin ürettikleri gerilim değerleri, akım değeri doğrusal değildir. Şekil 3'e göre en yüksek gerilim değerini MYH-III üretmiş olup onu MYH-II ve MYH-I takip etmiştir. Kutuplaşma eğrilerinde MYH-I, MYH-II ve MYH-III'ün ürettikleri en yüksek gerilim değerleri sırasıyla, $230 \mathrm{mV}, 455 \mathrm{mV}$ ve $503 \mathrm{mV}$ değerlerindedir. Tablo 1'deki veriler ve Şekil 3 kıyaslandığında, açık devre voltajları (Voc) ve dirençler üzerinde ölçülen voltajlar arasında büyük uçurumlar vardır. Voltaj verileri arasında belirgin bir şekilde ortaya çıkan fark, mikrobiyal yakıt hücrelerinin doğal çalışması nedeniyle ortaya çıkan iç dirençlerden kaynaklanmaktadır (Erensoy ve Çek (2018)). Bu durum, kompost mikrobiyal yakıt hücrelerinde güç kayıpları olduğunun göstergesidir.

Kutuplaşma eğrilerinde elde edilen gerilim değerleri, akım değerleri ve anot elektrot yüzey alanı, denklem (1)'e uygulanarak kompost mikrobiyal yakıt hücrelerinin güç yoğunluğu eğrileri oluşturulmuş ve Şekil 4’te verilmiştir.

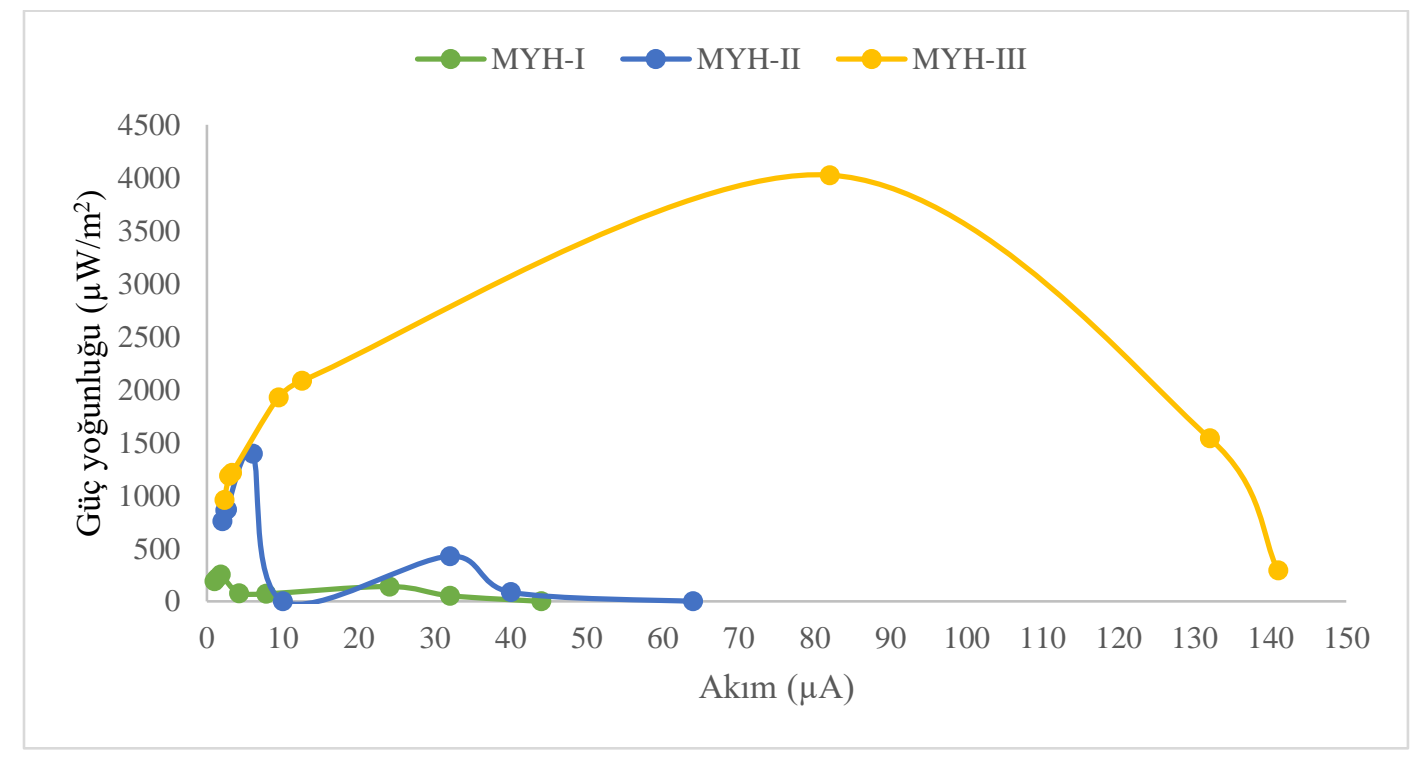

Şekil 4. Mikrobiyal yakıt hücrelerinin güç yoğunluğu eğrileri 
Şekil 4'e göre, MYH-I, MYH-II ve MYH-III kompost mikrobiyal yakıt hücrelerinin güç yoğunlukları sırasıyla, $255 \mu$ W/m² 1926.66 $\mu \mathrm{W} / \mathrm{m}^{2}$ ve $4025 \mu \mathrm{W} / \mathrm{m}^{2}$ olarak tespit edilmiştir. Görüldüğü gibi, MYH-III en yüksek güç yoğunluğuna sahip olan kompost mikrobiyal yakıt hücresidir. Ayrıca, en istikrarlı güç eğrisini MYH-III göstermiştir. Bu durum, kompost mikrobiyal yakıt hücrelerinde kullanılan organik malzeme miktarı arttıkça güç yoğunluğunun arttığını göstermektedir. Bu çalışmadaki MYH-III kompost mikrobiyal yakıt hücresinin ürettiği en yüksek güç yoğunluğu $\left(4.025 \mathrm{~mW} / \mathrm{m}^{2}\right)$ değerleri, Nandy ve ark. (2015) tarafindan yapılan kompost mikrobiyal yakıt hücresinin ürettiği en yüksek güç yoğunluğu $\left(4 \mathrm{~mW} / \mathrm{m}^{2}\right)$ değerinden biraz yüksektir. İki mikrobiyal yakıt hücresi arasındaki göze çarpan en büyük fark elektrot türlerinin farklı olmasıdır. Nandy ve ark. (2015) tarafından yapılan kompost mikrobiyal yakıt hücresinde karbon bez elektrotlar kullanılırken bu çalışmada titanyum levha elektrotlar kullanılmış ve yakın değerlerde güç yoğunluğu elde edilmiştir. Bu durum, titanyum levha elektrotların karbon bez elektrotlar ile benzer elektrokimyasal özellik gösterdiğinin bir göstergesidir. Bunlarla birlikte, Pareek ve ark. (2019) tarafından yapılan mikrobiyal yakıt hücresi çalı̧̧masında yakıt maddesi olarak atık sudaki organik maddeler kullanılmış ve bu mikrobiyal yakıt hücresinde birbirinden bağımsız olarak karbon bez, grafen oksit ve kimyasal olarak indirgenmiş grafen oksit elektrotlar kullanılmıştır. Karbon bez, grafen oksit ve kimyasal olarak indirgenmiş grafen oksit elektrotlar kullanılan çalışmada üretilen güç yoğunluğu değerleri sırasıyla, $0.8 \mathrm{~mW} / \mathrm{m}^{2}, 1.6 \mathrm{~mW} / \mathrm{m}^{2}$ ve $6 \mathrm{~mW} / \mathrm{m}^{2}$ olarak ifade edilmiştir (Pareek ve ark. (2019)). Bu çalışmadaki MYH-II ve MYH-III, Pareek ve ark. (2019) taradından yapılan çalışmadaki karbon bez ve grafen oksit kullanılan mikrobiyal yakıt hücrelerine göre daha yüksek güç yoğunluğuna sahiptir. Bu durum, titanyum elektrotun karbon beze ve grafen oksite alternatif bir elektrot olduğunu göstermektedir. Ayrıca bu çalışma, mikrobiyal yakıt hücresi uygulamaları için kompostlanmış toprağın atık suya alternatif bir organik madde kaynağı (yakıt kaynağı) olduğunu göstermektedir. Florio ve ark. (2019) tarafından yapılan mikrobiyal yakıt hücresi çalışmasında, yakıt kaynağı olarak organik atık ve elektrot olarak grafit plakalar kullanılmış ve kilogram başına en yüksek $1.98 \mathrm{~mW} / \mathrm{m}^{2}$ güç yoğunluğu elde edilmiştir. Bu çalışmadaki MYH-I, MYH-II ve MYH-III, Florio ve ark. (2019) tarafından yapılan çalışma ile kıyaslandığında MYH-III daha yüksek güç yoğunluğuna sahipken MYH-II ve MYH-I daha düşük güç yoğunluğuna sahiptir, ancak MYH-II'nin de güç yoğunluğu Florio ve ark. (2019) tarafindan yapılan çalışmaya yakındır. Bu kıyaslamalara göre, titanyum ile grafit elektrotların benzer performans gösterdiği hatta yüksek organik malzeme varlığında titanyum elektrotlar grafit elektrotlara göre daha etkin elektrokimyasal performans göstermiştir. Bu durum, mikrobiyal yakıt hücrelerinde titanyum elektrotların grafit elektrortlara alternatif bir elektrot olduğunun göstergesidir.

\section{Sonuç}

Mikrobiyal yakıt hücresi teknolojisi, fosil esaslı yakıt teknolojilerden yenilenebilir enerji sistemlerine geçişte büyük bir potansiyel sunmaktadır. Bu konuda yapılan araştırmalar hızla ilerlemektedir, ancak mikrobiyal yakıt hücresi teknolojilerinin sanayiye ve topluma rutin olarak uyarlanması için hala çok daha fazla ilerleme kat edilmesi gerekmektedir. Bu çalışmadaki, MYH-I, MYH-II ve MYH-III olarak adlandırılan kompost mikrobiyal yakıt hücrelerinde yapılan elektrokimyasal analizler, organik malzeme miktarının artması ile birlikte mikrobiyal yakıt hücrelerinin güç yoğunluğunun arttı̆̆ını göstermiştir. Ayrıca, güç eğrilerinde görüldüğü gibi organik malzeme miktarının artı̧ı güç eğrisinde dalgalanmaları (artma ve azalmaları) azaltmış, mikrobiyal yakıt hücrelerinin daha istikrarlı olmasını sağlamıştır. Tüm bunlar, organik malzemelerin mikrobiyal yakıt hücrelerinin çalışabilmesi için en önemli unsurlardan biri olduğunu bir kez daha göstermektedir. Bu çalışmadaki kimyasal ve mikrobiyal analizlere göre, coccus türü bakteriler biyokatalizör olarak görev yapmıştır. Bu nedenle coccus türü bakteriler, kompost organik malzemeyi ayrıştırarak elektron ve protonları açığa çıkarma işini yapmıştır. Bu durum coccus türü bakterilerin çürükçül olduğunu bir kez daha göstermiştir. Ayrıca, bu çalışmadaki mikrobiyal yakıt hücreleri diğer çalışmalarla kıyaslandığında onlardan daha yüksek veya yakın değerlerde güç yoğunluğuna sahiptir. $\mathrm{Bu}$ da, coccus tipi bakteriler, kompost malzeme ve titanyum elektrotlar arasında bir uyum olduğunun göstergesidir. Buna ilaven, diğer çalışmalarla yapılan kıyaslamalar açıkça gösteriyor ki, mikrobiyal yakıt hücreleri için titanyum elektrotlar, karbon bez, grafen ve grafit elektrotlara göre alternatif bir elektrot malzemesidir.

\section{Teşekkür}

Bu çalışmanın gerçekleşmesi için gerekli cihaz ve sarf malzemesi desteklerinden ötürü Koç Holding'e, Arçelik'e, TÜPRAŞ'a ve Fethi Gedik'e teşekkür ederiz.

\section{Kaynakça}

Baykara, S.Z., 2018. Sulfur Resistant Perovskite Electrocatalysts for High Temperature Applications. European Journal of Science and Technology, 13, 98-102.

Çek, N., 2013. Yeni Biyoenerji Tekniğiyle Elektrik Üretilmesi. Çukurova Üniversitesi Mühendislik ve Mimarlık Fakültesi Dergisi, 28(2), 35-49.

Çek, N., 2016a. Parçacıklar ve Enerji Kaynakları. Lambert Academic Publishing, 338 s, Saarbrucken, Almanya.

Çek, N., 2016b. Parçacıklar ve Parçacıkların Enerji Kaynakları Üzerinde Etkileri. Avrupa Bilim ve Teknoloji Dergisi, 4(7), 1-8.

Çek, N., 2017. Examination of zinc electrode performance in microbial fuel cells. Gazi University Journal of Science, 30(4), 395-402.

Erensoy, A., Çek, N., 2018. Alternative Biofuel Materials for Microbial Fuel Cells from Poplar Wood. ChemistrySelect, 3, 125111257.

Florio, C., Nastro, R.A., Flagiello, F., Minutillo, M., Pirozzi, D., Pasquale, V., Ausiello, A., Toscano, G., Jannelli, E., Dumontet, S., 2019. Biohydrogen production from solid phase-microbial fuel cell spent substrate: A preliminary study. Journal of Cleaner Production, 227, 506-511. 
Garita-Meza, M.A., Ramírez-Balderas, L.A., Contreras-Bustos, R., Chávez-Ramírez, A.U., Cercado, B., 2018. Blocking oscillatorbased electronic circuit to harvest and boost the voltage produced by a compost-based microbial fuel cell stack. Sustainable Energy Technologies and Assessments, 29, 164-170.

Güven, Ş.Y., 2014. Biyouyumluluk ve Biyomalzemelerin Seçimi. Süleyman Demirel Üniversitesi Mühendislik Bilimleri ve Tasarım Dergisi, 2(3), 303-311.

Moqsud, M. A., Omine, K., Yasufuku, N., Hyodo, M., Nakata, Y., 2013. Microbial fuel cell (MFC) for bioelectricity generation from organic wastes. Waste Management, 33(11), 2465-2469.

Moqsud, M. A., Yoshitake, J., Bushra, Q.S., Hyodo, M., Omine, K., Strik, D., 2015. Compost in plant microbial fuel cell for bioelectricity generation. Waste Management, 36, 63-69.

Nandy, A., Kumar, V., Khamrai, M., Kundu, P.P., (2015). MFC with vermicompost soil: power generation with additional importance of waste management. RSC Advances, 5, 41300-41306.

Pareek, A., Sravan, J.S., Mohan, S.V., 2019. Exploring chemically reduced graphene oxide electrode for power generation in microbial fuel cell. Materials Science for Energy Technologies, 2(3), 600-606.

Wang, C., Jiang, H., 2019. Real-time monitoring of sediment bulking through a multi-anode sediment microbial fuel cell as reliable biosensor. Science of The Total Environment, 697, 1-8. 